\title{
MAPPING DIGITAL FLUENCY IN DIVERSE SOCIO-ECONOMIC STATUS OF CITIZENS OF DKI JAKARTA 2017
}

\author{
Gilang Desti Parahita \\ Parahita.gilang@gmail.com \\ Universitas Gadjah Mada
}

\begin{abstract}
The loss of Ahok-Djarot, incumbent candidate pair, in the second round of gubernatorial election was allegedly related to the spread of digital disinformation. In addition, racial and religious sentiments in the society of DKI Jakarta have been fathomed evident in the last election. The phenomenon has driven a study on digital fluency in diverse socioeconomic status (SES) for example age, gender, religion, ethicity, religiousity, level of education and level of income in family. Survey was conducted to 189 voters of DKI Jakarta. Results show that respondents from different socioeconomic background have diverse digital fluency with the widest gaps occurred between people from lowest and highest level of religiosity, income and education. Respondents from different gender, age generation and religion background do not have considerable fluency gaps. However, using pearson correlational analysis, only level of income and education that predicts digital fluency level.
\end{abstract}

\begin{abstract}
Abstrak
Fenomena kekalahan Ahok-Djarot pada putaran kedua Pilgub DKI Jakarta tersebut ditengarai mudahnya warga termakan informasi digital bohong. Selain itu, sentimen ras dan agama di masyarakat DKI Jakarta yang selama ini bagaikan api dalam sekam dianggap terbukti pada Pilgub DKI terakhir. Fenomena tersebut mendorong dilakukannya riset mengenai tingkat kefasihan digital pada beragam status sosial ekonomi. Status sosial ekonomi yang dimaksud dalam konteks riset ini adalah ialah usia, gender, agama, etnis, tingkat kesalehan beragama, tingkat pendidikan, dan tingkat pendapatan dalam keluarga. Survei diselenggarakan terhadap 189 pemilih di DKI Jakarta. Temuan menunjukkan bahwa responden yang berlatar belakang beragam sosio ekonomi memiliki keragaman kefasihan digital pula dengan kesenjangan kefasihan tertinggi terjadi di antara kelompok responden berkelas tertinggi dan terendah di tingkat kesalehan, pendapatan dan pendidikan. Responden dari gender, generasi usia dan agama yang berbeda tidak menunjukkan kesenjangan fluensi yang patut dipertimbangkan. Selain itu, dengan menggunakan analisis korelasional, hanya level pendapatan dan pendidikan yang mempengaruhi level kefasihan digital
\end{abstract}

Keywords: Digital Fluency, Digital Disinformation, Socio-Economic Status 


\section{INTRODUCTION}

POLITICAL dynamics during the campaign phase of gubernatorial election of DKI Jakarta 2017 had become more interesting as political disinformation spread amongst local and national netizens. Different from digital misinformation which is more like an honest error or incaccuracy, digital disinformation is fake information that is intended to deceive people (Qazvinian, et.al., 2011; Tambuscio, 2016; Thorson, 2016). Some Indonesia's sites for example $B B C$ Indonesia, Detik.com (Amelia, 2016), and Turnbackhoax (http://Turnbackhoax.id) collected digital disinformation revolved during the campaign phase. The highlighted topics contained in digital disinformation include religious sentiments (anti-Christianity) and racial discriminations (anti-Chinese) in order to politically corner Basuki Tjahja Purnama, incumbent Governor who is a Chinese and Christian. Some of the digital disinformation are:

- A meme imitating Kompas.com site changed one word in the title of a news. It created newly misleading meaning from the initial and real news (Picture 1).
- Textual broadcast message distributed in social media and instant messaging saying that Ahok invited 500 troops from China to conquer demonstration defending Islam in October 2016;

- Fake article on Nahimunkar.com telling that Joko Widodo (current president who was previously a governor of DKI Jakarta) was shaking hands with Basuki Tjahja Purnama after the evictions of inhabitants of Bukit Duri;

- Fake article on Silahkan-sharee.blogspot. co.id writing that Basuki Tjahja Purnama is a follower of Indonesia's Communist Party (PKI).

Indonesian government has attempted to fight the spread of digital disinformation through lawful, regulatory and lobbying approaches. The government has started to block some sites that publish and spread lies (Ihsanuddin, 2017). However, this strategy seems prone to revive the power of state to control freedom of speech and press. Currently, the Ministry of Communication and Information has promoted to let over the top (OTT) services to develop technology that will be able to control the spread of

\section{NOMPIS.com

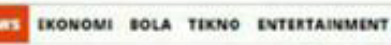

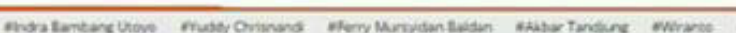 \\ Megapolitan}

News / Nezupoticis

Ahok: Kamu Kira Kami Niat Bangun Masjid dan Naikkan Haji Marbut?

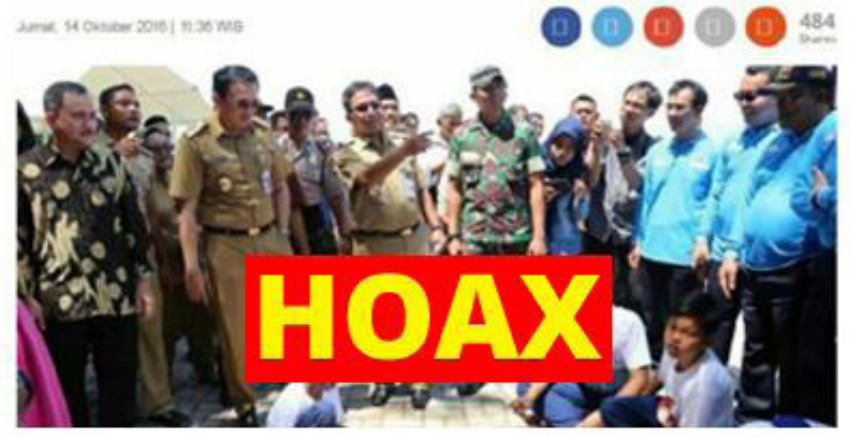

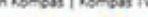

KOMPAS.com

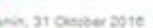

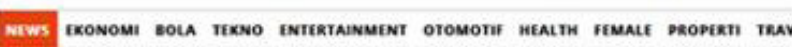

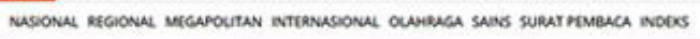

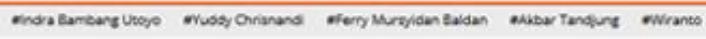

Ahok: Kamu Kira Kami Bohong Bangun Masjid, Naikkan Haji Marbut?

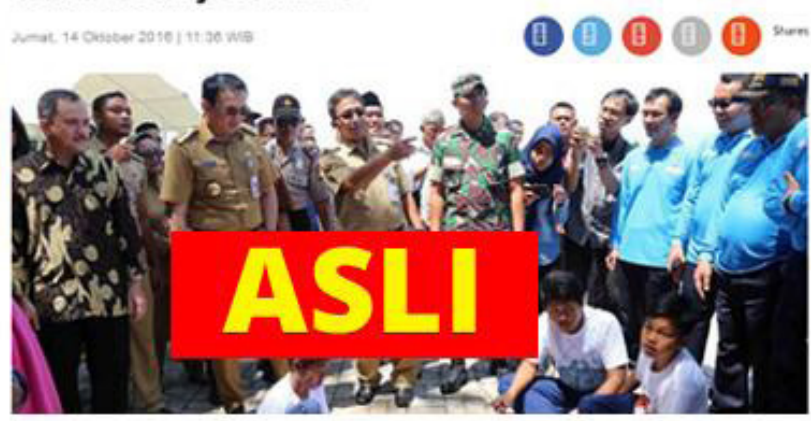

Picture 1. Hoax news contains, "Ahok: Do you think we intend to build mosque and send hajj?". Real and correct news, "Ahok: Do you think we lie we build mosque and send haji?" 
fake news (Anggraini, 2017). Press Council, additionally, applies policy allowing news media institutions to register themselves to the Council, proceed through verification process, and get Quick Response Code to be placed in front page of online or print news outlets (Prasetia, 2017). By this way, it is expected that citizens can recognize which news media is credible and which is not. However, it will take long time to verify thousands of press media in Indonesia and not every professional media even agree to follow the policy. The ineffectiveness of debunking the spread and implications of fake news by controlling the sources has inspired Telecommunication Society (Masyarakat Informasi/Mastel) to develop application and news sites (Sugiharto, 2017). Otherapproach is taken by Combine Resource Institutue (CRI). CRI has endorsed the empowerment of community media in order to reduce the spread and implication of fake news (Putra, 2017). Some online groups have organically developed in order to conquer digital disinformation for example Forum Anti Fitnah, Fanpage \& Grup Hoax Buster Indonesia and Grup Sekoci (Yusuf, 2017). All those efforts taken to decrease digital disinformation spread and implications seem are not effective. This is because the main key to stop and debunk digital disinformation is the citizens or users as they are the ones who receive, create, distribute, digest or criticize digital disinformation. Moreover, the rise of digital disinformation is considered to be related to the sinking trust of Indonesian citizens to mainstream media. According to "2016 Edelman Trust Barometer: Indonesia Results," the level of trust of Indonesian informed publics and general society towards media institution during 2016 has fallen five to ten percent compared to 2015 .

Therefore, digital fluency should have been well acquired by people especially when we consider multicultural society of Indonesia is also prone to intolerance and discrimination. Scholars have been concerning the access gap of information and communication literacy (ICT) amongst diverse socioeconomic groups especially in the issue of digital divide in some countries (Van Deursen, Helsper, Eynon, 2014; Luke, Dooley \& Woods, 2011; Ertl \& Helling, 2011; Henderson \& Honan, 20o8; Antonio \& Tuffley, 2014; Heinz, 2016; Brooks, et.al., 2005) and also in Indonesia (Rahman \& Quaddus, 2012; Yanti \& Alamsyah, 2014; Puspitasari \& Ishii, 2016; Lestariningsih, Hasyyati, Maharani, 2017). However, a country that is multicultural and in the same time has a high digital divide (and thus, fluency divide) can face rough times for developing healthy public sphere and discourse. The rising spread of false information during the gubernatorial election of DKI Jakarta, the capital city of Indonesia, is an example of how "digital fluency" gap has played. Some people are literate and fluent enough in using ICT ethically but some other are similarly literate and fluent but use ICT unethically. Utomo (et.al. 2013) captured the paradox of digital revolution in Indonesia which is internet penetration in the country remains low but the use of social media has reached second rank largest globally. It indicates that Indonesian people might have been familiar with social media but not with other digital actions. A research by Accenture (2016) confirms that digital fluency of Indonesian people is the lowest amongst studied countries.

The phenomenon of digital disinformation spread and highly use of social media amongst netizens of DKI Jakarta has raised some questions.

How are the index of digital fluency amongst Indonesian in each socioeconomic status, for example age, gender, ethnicity, religion, level of religiosity, level of economy, and level of education? How are the gaps of digital fluency amongst socioeconomic status?

Which socioeconomic status do predict highest and lowest level of overall digital fluency index? As digital disinformation has been rising during the gubernatorial election of DKI Jakarta, I also want to know from which online sources do netizens look for or verify accuracy and completeness of political information they get? 
We now live in digital society where information and communication technology (ICT) has been progressively adopted and integrated into domestic, educational, professional, and recreational activities. Anyone who wants to fit in living, learning and working in digital society requires cognitive, technical and ethical capability in using ICT which is called digital literacy (Gilster, 1997; Sharpe \& Beetham, 2010). Instead of being restrictive, many scholars have proposed that digital literacy is a developmental model (Sharpe \& Beetham, 2010; Van Deursen \& Van Dijk, 2009; Martin \& Grudziecki, 2006). For example, pyramid model of digital literacy consists of -from bottom to top part- access and awareness, skills, practices and identity (Sharpe \& Beetham, 2010). Therefore, digitally literate people do not only have access to ICT devices, they should master how to use, create, innovate and transform technology, content, identity, and even society. Later, Beetham (2015) builds a framework that assists in building digital capabilities in higher education and further education.

Some scholars prefer to use "digital fluency" instead of "digital literacy." "Literacy" as a term has been considered an obsolete concept while the word "fluency" indicates change (Bunz, Curry \& Voon, 2007). Digital fluency stresses the fact that existing skills can become developed and adaptive due to changes in technology. In accordance to them, Sainz Castano \& Artal (2008) points that similarly to digital literacy, digital fluency encompasses complex cognitive, technical and ethical competence however by the digital fluency individual and technology have adaptive capacity to manage and survive in digital environment. Briggs \& Makice (2011:11) underlines that digital fluency is the maximum individual potential to achieve desired outcomes through the use of digital technology. Somebody could be familiar with doing tasks using Microsoft Office however when business applications have shifted to social networks, blogs and wikis he or she could not be fluently using them.
In addition, Miller \& Bartlett (2012) suggests that "digital literacy" captures crosscutting elements of digital and information literacies as it refer to a set of contemporary skills necessary to exercise critical aspect of information literacy that eminently rooted in digital technology. Therefore, digital fluency encompasses the skill, knowledge framework, contemporary fluency and competence needed to assess, evaluate, value, synthesize, analyse and interpret the information's bias, integrity in the context of digital technology (Miller \& Bartlett, 2012). Resnick (2002:48) underlines that people who are digitally fluent do not only know how to use digital technology, but also know "how to construct things of significance with digital technology." He warns that "digital divide" will have different meaning which is "access gap" might be shrink but "fluency gap” could remain (Resnick, 2002:49).

Beetham's (2015) digital fluency model consists of six elements which are: (1) digital creation, innovation and scholarship; (2) communication, collaboration and participation; (3) information, data and media literacies; (4) digital learning and self-development; (5) digital identity and wellbeing; and (6) IT proficiency. The first element refers to the ability to create materials in a variety of digital technology forms, produce new solutions and practices using digital technologies, and discover and share new ideas using digital tools. Second element encompasses ability to communicate effectively and appropriately across a range of digital media for intended purpose and audience, collaborate with others, and participate effectively in digital communities safely and ethically. Third element is about the ability to interpret, create, store, share data digitally and to apply ethical, leggal and security requirements. Ability to use digital technology to improve oneself skills, to assist in learning process and record achievement is compouned in fourth element. The fifth element is the ability to develop and maintain appropriate personal and organisational digital identities, and reputation across a variety platforms. The sixth element refers 
to the ability to use a variety of devices, web, and mobile applications confidently, adapt and keep up with new developments in technology.

According to Miller \& Bartlet (2012), there are three components of digital fluency: net-savviness, critical evaluative techniques and diversity. Net savviness is a basic skill and practical understanding of the way digital and online technology work. It includes understanding of the way search engines search and provide results, how websites are developed, how online identity can be real or fake, how audio-visual products can be manipulated. Critical evaluative techniques refer to the ability and action of users to search check, combine, distinguish, and filter information. He or she will understand the quality level of information and is able to being sceptical to any digital information. Diversity means to what extent users consume broad, varied and diverse digital information and be aware of any biases contained in the messages. This component also includes ability of users in assessing and placing comments, opinions or any kind of digital contents in relevant categorization or ideological basis or public debate repertoire. Any users who are equipped with diversity component of digital literacy will be able to use websites that try to debunk hoaxes and fake news properly as those kinds of websites sometimes might also contain disinformation either.

This study combines six elements of digital fluency by Beetham (2015) and components of digital fluency of Miller \&
Bartlet (2012). Digital fluency then consists of several elements which are confidence, creation, action, ethics, privacy, personal development and criticality. Confidence element is about the required ability and mind-set to adapt the skills into different platforms of technology whether hardware or software varieties. Creation element is the knowledge and ability to produce digital and/ or online content or software. Action element is the ability to take digital/online actions. Ethics element is the knowledge, awareness and attitude about managing oneself in digital medium and its impact in broader society environment. Privacy element is the awareness about the consequences of loosening border between private and public life by the adoption of ICT and how oneself can protect themselves from the unsolicited privacy and personal information stealing. Personal development is the knowledge and ability to use in assisting personal development whether in career, education, and recreational activities. Criticality is the awareness and ability to be digest information in cautious manner by verifying, checking or comparing accuracy, completeness, and underlying logic of information or content shared through ICT.

Research investigates the predictors of digital fluency has been very limited (Green, 2005; Bologa, 2007; Wang, Myers \& Sundaram, 2012). Wang, Myers \& Sundaram (2012) have conducted literature review in order to investigate possible relationships of seven factors (demographic characteristics, psychological factors, social influences,

Table 1. Numbers of Population and Sample in Six Districts of DKI Jakarta (SUPAS 2015)

\begin{tabular}{|l|l|r|r|r|r|}
\hline No. & Districts & $\begin{array}{c}\text { Population } \\
\text { (ooo ppl) }\end{array}$ & $\begin{array}{c}\text { \% of } \\
\text { Population }\end{array}$ & \multicolumn{1}{c|}{ Sample } & \% of Sample \\
\hline 1 & Central Jakarta & 913,87 & 9,00 & 16 & 8,4 \\
\hline 2 & East Jakarta & $2.826,66$ & 27,84 & 69 & 36,1 \\
\hline 3 & South Jakarta & $1.283,90$ & 21,51 & 50 & 26,2 \\
\hline 4 & West Jakarta & $2.293,00$ & 24,23 & 24 & 12,6 \\
\hline 5 & North Jakarta & $1.745,82$ & 17,19 & 31 & 16,2 \\
\hline 6 & Thousand Islands & 23,31 & 0,23 & 1 & 0,5 \\
\hline & DKI Jakarta & $10.154,34$ & 100 & 191 & 100 \\
\hline
\end{tabular}

Source: SUPAS 2015 
Table 2. Questionnaire Design for Digital Fluency

\begin{tabular}{|c|c|c|c|}
\hline No. & Aspects & Questions & Scale of Responses \\
\hline $\mathbf{1}$ & Confidence & $\begin{array}{l}\text { I am confidence in using information and } \\
\text { communication devices }\end{array}$ & $\begin{array}{ll}\text { 1. } & \text { Very disagree } \\
2 . & \text { Disagree } \\
\text { 3. } & \text { Neutral } \\
\text { 4. } & \text { Agree } \\
\text { 5. } & \text { Very Agree }\end{array}$ \\
\hline 2 & Creation & $\begin{array}{l}\text { I know the production process of all } \\
\text { online (blogs, websites, crowdfunding } \\
\text { sites, online petition, social media, etc.). }\end{array}$ & $\begin{array}{ll}\text { 1. } & \text { Very disagree } \\
2 . & \text { Disagree } \\
\text { 3. } & \text { Neutral } \\
\text { 4. } & \text { Agree } \\
\text { 5. } & \text { Very Agree }\end{array}$ \\
\hline 3 & Action & $\begin{array}{l}\text { I can do actions on Internet contextually } \\
\text { (crowdsourcing, crowdfunding, online } \\
\text { petition, e-invitation, etc.). }\end{array}$ & $\begin{array}{ll}\text { 1. } & \text { Very disagree } \\
\text { 2. } & \text { Disagree } \\
\text { 3. } & \text { Neutral } \\
\text { 4. } & \text { Agree } \\
\text { 5. } & \text { Very Agree } \\
\end{array}$ \\
\hline 4 & Ethics & $\begin{array}{l}\text { I understand the possible lawful impact } \\
\text { of my online actions. }\end{array}$ & $\begin{array}{ll}\text { 1. } & \text { Very disagree } \\
\text { 2. } & \text { Disagree } \\
\text { 3. } & \text { Neutral } \\
\text { 4. } & \text { Agree } \\
\text { 5. } & \text { 5Very Agree }\end{array}$ \\
\hline 5 & Privacy & I know how to protect my digital privacy. & $\begin{array}{ll}\text { 1. } & \text { Very disagree } \\
2 . & \text { Disagree } \\
\text { 3. } & \text { Neutral } \\
\text { 4. } & \text { Agree } \\
\text { 5. } & \text { Very Agree } \\
\end{array}$ \\
\hline 6 & Skills & $\begin{array}{l}\text { I know how to use digital technology to } \\
\text { edit pictures, video and voices. }\end{array}$ & \begin{tabular}{|ll} 
1. & Very disagree \\
2. & Disagree \\
3. & Neutral \\
4. & Agree \\
5. & Very Agree \\
\end{tabular} \\
\hline 7 & $\begin{array}{l}\text { P e r s o n a } 1 \\
\text { Development }\end{array}$ & I use ICT for my personal development. & $\begin{array}{ll}\text { 1. } & \text { Never } \\
\text { 2. } & \text { Sometimes } \\
\text { 3. } & \text { Average } \\
\text { 4. } & \text { Often } \\
5 . & \text { Always } \\
\end{array}$ \\
\hline 8 & Criticality & $\begin{array}{l}\text { I look for other sources to compare } \\
\text { information. }\end{array}$ & \begin{tabular}{|ll} 
1. & Never \\
2. & Sometimes \\
3. & Average \\
4. & Often \\
5. & Always
\end{tabular} \\
\hline
\end{tabular}

educational factors, behavioural intention, opportunity and actual use of technology) to digital fluency. However, they have not reached actual results yet. Green (2005) dissertation shows the regression analysis between demographic such as race and age and personality with digital fluency.
Meanwhile, digital literacy studies have reached mature discussion. The scholarships of digital fluency have investigated the gap of digital literacies amongst socio-groups and the factors contribute to the gaps (Bulger, Mayer, \& Metzger, 2014; Jackson, et.al. 2008) and even the relationships between digital 
literacy with teaching (Greene \& Copeland, 2014).

Socioeconomic factors, though they do not explain directly why somebody psychologically tends to perceive fake news as truth, are able to illuminate in which socioeconomic groups some people show higher or lower tendencies to believe digital disinformation. This approach in understanding digital fluency is inspired by some research.

\section{METHOD}

\section{Sampling \& Data Collection}

Three enumerators collected data with the assistance of Suveymonkey.com. The sample is DKI Jakarta's citizens who have valid DKI Jakarta ID-Card. They are also eligible for voting in 2016-2017 whether they used their rights or they did not. The survey was launched on 15-25 July 2017.

Based on the data of population census of 2015 (SUPAS 2015), the survey expected to have some numbers of respondents in each district (Table 1). The gender distribution was based on the proportion of male and female citizens of DKI Jakarta which is 102:100 (SUPAS 2015).

Questionnaires were distributed to 231 citizens of DKI Jakarta however only 191 questionnaires were fully completed on online via Surveymonkey.com. Based on the data (Table 3), mostly respondents were from East Jakarta (36,1\%) and South Jakarta (26,2 $\%)$. North Jakarta and West Jakarta shared almost the same percentages of respondent which are $16,2 \%$ and $12,6 \%$. Fewest percentage of respondent is from Thousand Islands ( 0,5 $\%)$. It already represents the population of DKI Jakarta as reported by SUPAS 2015. The gender distribution was also consistent with SUPAS 2015 data which shows a balance proportion between male and female (Table 2).

\section{Survey Design \& Measurement}

The questionnaire requested respondents to answer socioeconomic variables with categorical responses (gender, religion, ethnicity) while some others use ordinal (educational level), interval (age), orderedcategory scales (level of income in family, level of religiosity). Meanwhile, digital fluency variable uses Likert scale for questioning its elements and ordered category scales for detailing the criticisms to digital content.

\section{Analysis Technique}

There are some techniques used to analyse the data. To answer the first question, descriptive analysis of mean and standard deviation is applied. The first question is about the index of digital fluency amongst Indonesian in each socioeconomic status. Pearson correlation analysis is used to answer the second question about which socioeconomic status predict the highest and lowest level of all fluency index. Answering the third question which is about from which online sources do respondents refer to verify online information utilizes mean analysis?

Tabel 3. Numbers of Population and Sample in Six Districts of DKI Jakarta (SUPAS 2015)

\begin{tabular}{|r|l|r|r|r|r|}
\hline No. & Districts & \multicolumn{1}{c|}{$\begin{array}{c}\text { Population } \\
\text { (ooo ppl) }\end{array}$} & $\begin{array}{c}\text { \% of } \\
\text { Population }\end{array}$ & \multicolumn{1}{c|}{ Sample } & \% of Sample \\
\hline 1 & Central Jakarta & 913,87 & 9,00 & 16 & 8,4 \\
\hline 2 & East Jakarta & $2.826,66$ & 27,84 & 67 & 35,4 \\
\hline 3 & South Jakarta & $1.283,90$ & 21,51 & 50 & 26,2 \\
\hline 4 & West Jakarta & $2.293,00$ & 24,23 & 24 & 12,6 \\
\hline 5 & North Jakarta & $1.745,82$ & 17,19 & 31 & 16,2 \\
\hline 6 & Thousand Islands & 23,31 & 0,23 & 1 & 0,5 \\
\hline & DKI Jakarta & $10.154,34$ & 100 & 189 & 100 \\
\hline
\end{tabular}

Source: SUPAS 2015 


\section{RESULT AND DISCUSSION}

\section{Profile of Respondents}

There are finally 189 completed questionnaires from 191 questionnaires sent back to enumerators. Most respondents are from East Jakarta $(35,4 \%)$ and the least are from Thousand Islands $(0,5 \%)$ table 3 .

The gender of 189 respondents consists of $48,7 \%$ male and $51,3 \%$ of female (Table 4). It resonates with the data of SUPAS 2015 which shows that the proportion of male and female is almost equal.

Table 4. Gender

\begin{tabular}{|c|r|r|r|r|}
\hline & Frequency & Percent & $\begin{array}{c}\text { Valid } \\
\text { Percent }\end{array}$ & $\begin{array}{c}\text { Cumulative } \\
\text { Percent }\end{array}$ \\
\hline male & 92 & 48.7 & 48.7 & 48.7 \\
Valid female & 97 & 51.3 & 51.3 & 100.0 \\
Total & 189 & 100.0 & 100.0 & \\
\hline
\end{tabular}

The respondents were mostly born in 1986-200 (68,8 \%). Meanwhile, the rest was born in 1971-1985 (28,6\%) (Table 5). The concentration of age distribution of respondents into only two generations seems caused by the penetration of online questionnaires that were mostly shared between smartphone owners.

Table 5. Age

\begin{tabular}{|c|r|r|r|r|}
\hline & Frequency & Percent & $\begin{array}{c}\text { Valid } \\
\text { Percent }\end{array}$ & $\begin{array}{c}\text { Cumulative } \\
\text { Percent }\end{array}$ \\
\hline $\begin{array}{l}1986- \\
2000\end{array}$ & 130 & 68.8 & 68.8 & 68.8 \\
$\begin{array}{l}1971- \\
\text { Valid } \\
1985\end{array}$ & 54 & 28.6 & 28.6 & 97.4 \\
3 & 5 & 2.6 & 2.6 & 100.0 \\
Total & 189 & 100.0 & 100.0 & \\
\hline
\end{tabular}

Given the domination of Islam in Indonesia and of course in DKI Jakarta, 79,4 $\%$ respondents are moslem and the rest is other than moslem (Table 6).

Table 6. Religion

\begin{tabular}{|r|r|r|r|r|}
\hline & Frequency & Percent & $\begin{array}{r}\text { Valid } \\
\text { Percent }\end{array}$ & $\begin{array}{c}\text { Cumulative } \\
\text { Percent }\end{array}$ \\
\hline Islam & 150 & 79.4 & 79.4 & 79.4 \\
Other & 39 & 20.6 & 20.6 & 100.0 \\
Valid $\begin{array}{l}\text { than } \\
\text { Islam }\end{array}$ & 189 & 100.0 & 100.0 & \\
Total & & & & \\
\hline
\end{tabular}

Middle class status seems dominate the income level in the family of respondents (Table 7 ). It shows that $51,9 \%$ and $43,4 \%$ of the respondents acknowledge themselves as part of middle up and middle low economic status. Similar with the age distribution, the respondents were concentrated in high, middle up, and middle low statuses because the online questionnaires were mostly distributed amongst holders of ID of DKI Jakarta who owned smartphones.

Table 7. Income Level in the Family

\begin{tabular}{|c|r|r|r|r|}
\hline & Frequency & Percent & $\begin{array}{r}\text { Valid } \\
\text { Percent }\end{array}$ & $\begin{array}{c}\text { Cumulative } \\
\text { Percent }\end{array}$ \\
\hline High & 8 & 4.2 & 4.2 & 4.2 \\
Middle & 98 & 51.9 & 51.9 & 56.1 \\
Up & & & & \\
Valid Middle & 82 & 43.4 & 43.4 & 99.5 \\
Low & 1 & .5 & .5 & 100.0 \\
Low & 189 & 100.0 & 100.0 & \\
Total & & & \\
\hline
\end{tabular}

Compared to income level and age of respondents, the educational level is more diverse. There were some respondents graduated from elementary/ junior high school (1,6\%) and master/ doctoral degree $(12,2 \%)$. Many of respondents hold senior high school and diploma/ bachelor degree.

Table 8. Educational Level

\begin{tabular}{|l|r|r|r|r|}
\hline & Frequency & Percent & $\begin{array}{r}\text { Valid } \\
\text { Percent }\end{array}$ & $\begin{array}{c}\text { Cumulative } \\
\text { Percent }\end{array}$ \\
\hline ES/JHS & 3 & 1.6 & 1.6 & 1.6 \\
SHS & 59 & 31.2 & 31.2 & 32.8 \\
Diploma/ & 104 & 55.0 & 55.0 & 87.8 \\
Valid $\begin{array}{l}\text { Bachelor } \\
\text { Master/ }\end{array}$ & 23 & 12.2 & 12.2 & 100.0 \\
Doctoral & & & & \\
Total & 189 & 100.0 & 100.0 & \\
\hline
\end{tabular}

\section{Index of Digital Fluency Level amongst Socio-economic Status}

There were 189 completed questionnaires. The questionnaire consists of eight main questions (Table 8). Respondents answered in a Likert Scale which is strongly disagree (1), disagree (2), neutral (3), agree (4), and very agree (5). Respondents who answered very agree meant they are comply with the characteristics of digitally fluent people. Therefore, the mean of each of 
socioeconomic status represents the digital fluency level in the scale of five.

Based on the data (Table 9), the digital fluency level amongst people from different socioeconomic status is diverse. The study considers that the level of digital fluency consists of low (o,1-1,6 of mean), average (1,73,2 of mean) and high (3,3-5 of mean). Using the scale, we can summarize some facts as below:

a. Male respondents tend to have slightly higher digital fluency than female ones;

b. People born in 1971-1985 tend to have high digital fluency meanwhile those born in 1986-200o are average;

c. People who have religion other than Islam tend to have high digital fluency meanwhile those who are Muslim are average;

d. People who are more religious tend to have high digital fluency meanwhile the less religious ones are average; e. People who have high or middle-up level of income in the family tend to have high digital fluency meanwhile other who have less income are average;

f. People who have master/ doctoral educational level tend to have high digital fluency meanwhile other who are less educated are average.

Despite to the fact that differences of gender, age and religion have shown different level of digital fluency, Table 9 has also shown that digital fluency gaps amongst those three socioeconomic status are not wide. The values of the gaps are only at $o$, o5 (age), o, 07 (gender) and o,o8 (religion) or less than 0,1 in average. The relatively high gap of digital fluency appears amongst people in different level of religiosity, income in family and education. The fluency gap between the lowest and highest status of some socioeconomic factors is more than 0,1 which is o,4 (religiosity), o,7 (income level) and 1,1 (educational level).

Table 9. Descriptive Analysis of Socioeconomic Factors \& Digital Fluency

\begin{tabular}{|c|c|c|c|c|c|}
\hline $\begin{array}{c}\text { Socioeconomic } \\
\text { Factor }\end{array}$ & Status & Missing & $\mathrm{N}$ & Mean & $\begin{array}{c}\text { Standard } \\
\text { of } \\
\text { Deviation }\end{array}$ \\
\hline \multirow{2}{*}{ Gen } & Male & \multirow{2}{*}{0} & \multirow{2}{*}{189} & 3.30 & 0.522 \\
\hline & Female & & & 3.23 & 0.657 \\
\hline \multirow{2}{*}{ Age } & $1986-2000$ & \multirow{2}{*}{0} & \multirow{2}{*}{189} & 3.26 & 0.594 \\
\hline & 1971-1985 & & & 3.31 & 0.569 \\
\hline \multirow[b]{2}{*}{ Religion } & Islam & \multirow[b]{2}{*}{0} & \multirow[b]{2}{*}{189} & 3.25 & 0.620 \\
\hline & $\begin{array}{l}\text { Other than } \\
\text { Islam }\end{array}$ & & & 3.33 & 0.485 \\
\hline \multirow{5}{*}{ Religiosity } & Very Low & \multirow{5}{*}{0} & \multirow{5}{*}{189} & 3.15 & 0.672 \\
\hline & Low & & & 3.22 & 0.51 \\
\hline & Average & & & 3.26 & 0.617 \\
\hline & High & & & 3.30 & 0.570 \\
\hline & Very high & & & 3.55 & 0.422 \\
\hline \multirow{4}{*}{ Econ. } & Low & \multirow{4}{*}{0} & \multirow{4}{*}{189} & 2.90 & 0.568 \\
\hline & Middle Low & & & 3.16 & 0.586 \\
\hline & Middle Up & & & 3.43 & 0.571 \\
\hline & High & & & 3.64 & 0.516 \\
\hline \multirow{3}{*}{ Educ. } & ES/JHS & \multirow{3}{*}{0} & \multirow{3}{*}{189} & 2.50 & 0.725 \\
\hline & $\begin{array}{l}\text { Diploma/ } \\
\text { Bachelor }\end{array}$ & & & 3.26 & 0.617 \\
\hline & Master/Doctoral & & & 3.63 & 0.515 \\
\hline
\end{tabular}




\section{SES Predicting Level of Digital Fluency}

Although the mean analysis of the data has shown that the digital fluency and fluency gaps amongst socioeconomic status are diverse, it is unable to show which socioeconomic factor affects the digital fluency. Pearson correlational analysis is then applied to see which socioeconomic status affecting the digital fluency. If the P-Value of each socioeconomic factor is more than 0,005 , the null hypothesis is accepted. The assumption that become null hypothesis in the analysis is that the each socioeconomic factor does not affect digital fluency. The result eventuallyperforms that the P-Values of religiosity, age, gender and religion are more than 0,005 therefore the null hypotheses of them are accepted. This also means that the predictors for digital fluency of DKI Jakarta's voters are educational level and income level (table 10.)

Educational and income level become important elements in assessing whether somebody or some groups of DKI Jakarta voters have high digital fluency. We can expect that those who hold doctoral and master degree have higher chance than those who only hold high school education to be better in differenciating fake news from real news.

Table 1o. P-Value of SES towards Digital Fluency

\begin{tabular}{|c|c|c|}
\hline Variables & Pearson Correlation & P-value \\
\hline $\begin{array}{c}\text { Digital fluency average, } \\
\text { educational level }\end{array}$ & 0.238 & 0.001 \\
\hline $\begin{array}{c}\text { Digital fluency average, income } \\
\text { level }\end{array}$ & 0.257 & 0.000 \\
\hline Digital fluency average, religiosity & 0.070 & 0.337 \\
\hline Digital fluency average, age & 0.001 & 0.986 \\
\hline Digital fluency average, gender & -0.058 & 0.424 \\
\hline Digital fluency average, religion & 0.052 & 0.478 \\
\hline
\end{tabular}

Table 11. Mean of Digital Sources for Verifying Accuracy of Online Political Information

\begin{tabular}{|l|l|l|l|l|l|r|}
\hline \multirow{2}{*}{ No. } & \multirow{2}{*}{ Digital Media } & \multicolumn{5}{c|}{ Responses } \\
\cline { 3 - 7 } & & \multicolumn{1}{|c|}{$\mathrm{Nv}$} & \multicolumn{1}{c|}{$\mathrm{Sm}$} & \multicolumn{1}{c|}{$\mathrm{Av}$} & \multicolumn{1}{c|}{ Of } & $\mathrm{Al}$ \\
\hline 1 & Websites & 0,049 & 0,024 & 0,287 & 0,309 & 0,104 \\
\hline 2 & Social Media & 0,143 & 0,226 & 0,331 & 0,215 & 0,077 \\
\hline 3 & Instant Messaging & 0,110 & 0,309 & 0,281 & 0,209 & 0,883 \\
\hline
\end{tabular}

Nv Never

Sm Sometimes

Av Average

Of Often

Al Always

Table 12. Mean of Digital Sources for Verifying Completeness of Online Political Information

\begin{tabular}{|l|l|l|l|l|l|l|}
\hline \multirow{2}{*}{ No. } & \multirow{2}{*}{ Digital Media } & \multicolumn{5}{|c|}{ Responses } \\
\cline { 3 - 7 } & & \multicolumn{1}{|c|}{$\mathrm{Nv}$} & \multicolumn{1}{|c|}{$\mathrm{Sm}$} & \multicolumn{1}{c|}{$\mathrm{Av}$} & \multicolumn{1}{c|}{ Of } & $\mathrm{Al}$ \\
\hline 1 & Websites & 0,049 & 0,292 & 0,320 & 0,237 & 0,009 \\
\hline 2 & Social Media & 0,182 & 0,259 & 0,303 & 0,176 & 0,077 \\
\hline 3 & Instant Messaging & 0,165 & 0,259 & 0,353 & 0,149 & 0,071 \\
\hline
\end{tabular}




\section{Online Sources for Verifying Online Political Information}

Digital disinformation about politics of DKI Jakarta is spread through social media and instant messaging applications. This has caused confusion amongst netizens. All the respondents (189) answered that they compare political information received digitally whether through smartphone, personal computer or laptop. They then were asked about which digital sources they refer in order to verify accuracy and completeness of online political information. They were provided with three kinds of digital media: websites, social media and instant messaging. Each respondent was required to choose one from five ordered scale (never to always). The data (Table 11) above shows the average (Mean) of respondents who answered the five ordered scale. Therefore, the higher average number shown is, the more respondents refer to it which could be never, or sometimes, or average, or often, or always.

The data shows that the respondents who answer "always" looking for political information from instant messaging in order to verify accuracy of the information they previously get received the highest average $(0,833)$. It seems that the respondents might share information they receive on instant messaging services then they also get the feedbacks denying or confirming the information from their social networks in the instant messaging services. In other words, the respondents do not rely on websites or social media to seek the accuracy of political information during the gubernatorial election of DKI Jakarta, but they rely on the people who are available in their instant messaging services. It could also indicate that the respondents loved to gossip about the politics on the services.

The responses on question about which digital media they look for verifying completeness of online political information seem unreliable as mostly they answered average for each digital media (Table 12). It means that they might not be able to understand the meaning of "information completeness" itself, or the respondents do not put any attention on completeness of information as what they might care more is about the 'speed' aspect of information or news.

\section{CONCLUSION}

Digital fluency has been regarded very important lately. Some countries have integrated digital fluency in their curriculum (White, 2013). Digital fluency is even considered as the foundation for digital citizenship and the key to closing gender inequality in workplaces (Netsafe, 2016; Accenture \& Femina, 2016). Especially in a culturally diverse as in Indonesia, digital fluency might help to anticipate the increasing victims and criminals of online bullying, hoax, and fraud. However, the digital fluency of digital citizens in countries including Indonesia is not well pictured. This study provides the digital fluency amongst voters of DKI Jakarta who had vote rights in gubernatorial election of 2017.

The study concludes that there are no evident in predicting somebody's digital fluency through gender, age generation, religion, and religiosity. Digital fluency gaps between those factors are also low -except the religiosity factor. Respondents who have higher level of religiosity tend to have better score in digital fluency. However, religiosity level does not predict digital fluency. In other hand, level of income and education show significant relationships with digital fluency level. The more somebody has high level of income, the higher chance one has well digital fluency. In addition, the more somebody has high educational level, the higher opportunity one poses digital fluency. Instant messaging services become the most favorited source to refer for verifying the accuracy of online political information amongst the respondents during the gubernatorial election of 2017 .

The limitations of the study is the context of facts was bounded to the gubernatorial election of DKI Jakarta in 2017. The respondents were restricted to those who have had voting rights at that time and have accessed smartphone or other information 
and communication technology (ICT) means. Therefore, the data does not represent the citizens of DKI Jakarta in general, but citizens of DKI Jakarta who have voting rights and ICT means in 2017. However, this study is able to become a starting point to describe the potential of digital citizenships of DKI Jakarta citizens. Future research should investigate more about how the local culture, local community, or psychological state enables or disables citizens in being sceptical to digital information on politics.

\section{Acknowledgement}

This research was funded by Junior Researcher Grant of LPPM Universitas Gadjah Mada, Indonesia Year 2017. This research was assisted by Agustinus Beo Da Costa, Raisya Maharani, Muhammad Irham, and Jalal Albaghsi. Thank you for your all supports.

\section{REFERENCES}

Accenture \& Femina. (2016). Getting to Equal: How digital is helping close the gender gap at work. Digital Fluency Indonesia Report, retrieved from https://www.accenture.com/ t20160506To60137__w__/id-en/_ acnmedia/Accenture/ConversionAssets / DotCom/Documents / About-Accenture/PDF/3/AccentureIWD-2016-Digital-Fluency-IndonesiaReport.pdf.

Amelia, M. "Beredar Informasi Intelijen Soal Kasus Ahok di Medsos, BIN: Itu Hoax!" November 17, (2016). URL: http://news. detik.com/berita/d-3348136/beredarinformasi-intelijen-soal-kasus-ahokdi-medsos-bin-itu-hoax.

Anggraini, E. "Kiat Menkominfo Tangkal Penyebaran Berita Hoax." CNN Indonesia, February 1, (2017). URL: http://www.cnnindonesia.com/ teknologi/20170131142258-185-190284/ ki a t-men ko m in fo-tang ka lpenyebaran-berita-hoax/

Antonio, A. \& Tuffley, D. (2014). The gender digital divide in developing countries. Future Internet, 6(4):673-687.

BBC Indonesia. "Hoax Seputra Kasus Ahok, FPI, 4 November." November 3, 2016. URL: http://www.bbc.com/indonesia/ trensosial-37843842.

Bunz, U., Curry, C. and Voon, W. (2007). 'Perceived versus actual computeremail-web fluency'. Computers in Human Behavior, 23, pp. 2321-2344.

Beetham, H. (2010). Review and scoping study for a Cross-JISC Learning and digital literacies programme. Available from http://www.jisc.ac.uk/media/ documents/programmes/elearning/ DigitalLiteraciesReview.pdf.

Beetham, H. (2015, June 15) Revisiting Digital Capability for 2015. [Jisc digital 
capability codesign challenge blog] Available from: http://digitalcapability. jiscinvolve.org/wp/2015/o6/11/ revisiting-digital-capability-for-2015.

Bologa, R.,et.al.. (2007). Digital Fluency and Its Importance in Educating Young Students for the Knowledge Age, Proceedings of the 7 th WSEAS International Conference on Ditance Learning and Web Engineering, Beijing, China, September 15-17, 2007.

Bulger, M.E. Mayer, R.E., \& Metzger, M.J. (2014). Knowledge and processes that predict proficiency in digital literacy. Reading \& Writing, Vol. 27(9):15671583).

Edelman Trust Barometer. (2016). 2016 Edelman Trust Barometer: the State of Trust.

Ertl, B. \& Helling, K. (2011). Promoting gender equality in digital literacy. Educational Computing Research, Vol. 45(4):477503.

Gilster, P. (1997). Digital literacy. New York: John Wiley.

Green, R.M. Predictors of digital fluency. Ph.D. thesis, Northwestern University.

Greene, J.A. \& Copeland, D.Z. (2014). Measuring critical components of digital literacy and their relationships with learning. Computers E Education, Vol. 76:55-69.

Heinz, J. (2016). Digital Skills and the Influence of Students' Socio-Economic Background. An Exploratory Study in German Elementary Schools. Italian Journal of Sociology of Education, $8(2), \quad 186-212$. doi: 10.14658/pupjijse-2016-2-9

Henderson, Robyn, and Eileen Honan. "Digital literacies in two low socioeconomic classrooms: Snapshots of practice." English Teaching 7.2 (2008): 85 .
Ihsanuddin. "Ini Dia 11 Situs terbaru yang Diblokir Pemerintah." Kompas.com., January 4, 2017. URL: http://tekno.kompas.com/ read/2017/o1/o4/10150067/ini. dia.11.situs.yang.terbaru.diblokir. pemerintah.

Lestariningsih, E., Hasyyati, A.N., Maharani, K. (2017). Internet access and digital divide in Indonesia. Proceesings of 2 nd Regional Statistics Conference, Jakarta, Indonesia, March 20-24, 207.

Linda A. Jackson, Yong Zhao, Anthony Kolenic III, Hiram E. Fitzgerald, Rena Harold, and Alexander Von Eye. CyberPsychology \& Behavior. August 2008, 11(4): 437-442.

Martin, A., \& Grudziecki, J. (2006). DigEuLit: Concepts and tools for digital literacy development. Innovation in Teaching and Learning in Information and Computer Science,

Martin, A. (2006). 'Literacies for the Digital Age'. In Martin, A. \& Madigan, D. (Eds.) Digital Literacies for Learning. London, Facet, pp. 3-25.

Netsafe. (2016). From literacy to fluency to citizenship: Digital citizenship in education. Retrieved from https://www.netsafe.org.nz/wpcontent/uploads/2016/11/NETSAFEWHITEPAPER-From-literacy-tofluency-to-citizenship.pdf.

Ogunsola, L.A. \& Okusaga, T.O. (2006). Digital Divide Between Developed and Less-Developed Countries: The Way Forward. J. Soc. Sci., 13(2): 137-146.

Prasetia, A. "Perangi Hoax, Dewan Pers Siapkan QR Code Label Media Terpercaya." Detik.com, January, 9, 2017. URL: https://news.detik.com/ berita/d-3390984/perangi-hoaxdewan-pers-siapkan-qr-code-labelmedia-terpercaya

Putra, F.F. "Mendudukkan Media Komunitas dalam Perang Melawan Hoax." Combine.or.id., Feburary 3, 2017. URL: 
https://www.combine.or.id/2017/02/ mendudukkan-media-komunitasdalam-perang-melawan-hoax/

Puspitasari, L. \& Ishii, K. (2016). Digitaldivides and mobile Internet in Indonesia: Impact of smartphone. Telematics $\mathcal{E}$ Informatics, Vol. 33(2):472-483.

Qazvinian, V., Rosengren, E., Dragomir, R., Qiaozhu, R. (2011). Rumor Has It: Identifying Misinformation in Microblogs. Proceedings of the 2011 Conference on Empirical Methods in Natural Language Processing, 15891599, Edinburg, Scotland, UK, July 2731, 2011

Rahman, A.R. \& Quaddus, M. (2012). Qualitative Investigation of Digital Divide. Proceeding of 23rd Australasian Conference on Infomation Systems, Geelong, Dec, 3-5, 2012.

Resnick, M. (2002). Rethinking learning in the digital age. In G. Kirkman (Ed.), The global information technology report: Readiness for the networked world. Oxford, UK: Oxford University Pres.

Ritzhaupt, A. D., Liu, F., Dawson, K., \& Barron, A. E. (2013). Differences in student information and communication technology literacy based on socioeconomic status, ethnicity, and gender: Evidence of a digital divide in Florida schools. Journal of Research on Technology in Education, 45(4), 291307.

Sáinz, M., Castaño, C. \& Artal, M. (2008). Review of the concept "digital literacy" and its implications on the study of the gender digital divide [working paper online]. UOC. (Working Paper Series; WPo8-oo1). http://www.uoc.edu/in3/ $\mathrm{dt} / \mathrm{eng} /$ sainz_castano_artal.pdf [last accessed 23 rd June 2010].

Sharpe, R. and Beetham, H. (2010) Understanding students' uses of technology for learning: towards creative appropriation. In R. Sharpe, H. Beetham and S. De Freitas (eds.)
Rethinking learning for a digital age: how learners are shaping their own experiences. London and New York: Routledge.

Sugiharto, B.A. "Turn Back Hoax: Aplikasi Tangkal Konten Palsu Buatan Mastel.” CNN Indonesia, February 13, (2017). URL: http://www.cnnindonesia.com/ teknologi/20170213160056-185-193214/ turn-back-hoax-aplikasi-tangkalkonten-palsu-buatan-mastel/

Tambuscio, M., et.al., (2016). Network Segregation in a Model of Misinformation and Fact Checking. Diunduh di https://arxiv.org/ pdf/1610.04170.pdf.

Thorson, E. (2016). Belief Echoes: The Persistent Effects of Corrected Misinformation. Political Communication, 33: 460-480.

Utomo, A., et.al. (2013). Digital inequalites and young adults in Greater Jakarta: A Socio-demographic Perspective. Internationa Journal of Indonesian Studies, Vol. 1(79): 79-109.

Van Deursen, A., \& Van Dijk, J. (2009). Improving digital skills for the use of online public information and services. Government Information Quarterly, 26, 333-340

Van Deursen, A.J.A.M., Helsper, E.J. \& Eynon, R. (2014). Measuring Digital Skills. From Digital Skills to Tangible Outcomes project report. Available at: www.oii. ox.ac.uk/research/projects/?id=112.

Wang, E.Myers, M.D., \& Sundaram, D. (2012). Digital Natives and Digital Immigrants: Towards a Model of Digital Fluency. European Conference on Information Systems (ECIS) 2012 Proceeding.

White, G.K. (2013). Digital Fluency: Skills Necessary for Learning in the Digital Age. Digital Learning Research, Melbourne: ACER.

Yanti, M. \& Alamsyah. (2014). Determinant of digital divide in Indonesia: the Case 
of South Sumatra Province. Afro Asian Journal of Social Sciences, Vol. 5(5.1 Quarter).

Yusuf, O. "Perlawanan Netizen Lahirkan Masyarakat Anti-Hoax." Kompas. com, January 8, (2017). URL: h t t p:// tekno.kompas.com / read/2017/o1/o8/10495047/ perlawanan.netizen.lahirkan. masyarakat.anti-.hoax. 
INFORMASI Kajian Ilmu Komunikasi Volume 47. Nomor 2. Desember 2017 